\title{
SISTEM INFORMASI PENJADWALAN CERAMAH MENGGUNAKAN ALGORITMA GREEDY
}

\author{
Suci Ayu Mawarni ${ }^{1}$, Zarnelly $^{2}$, Arif Marsal ${ }^{3}$ \\ Program Studi Sistem Informasi, Fakultas Sains dan Teknologi \\ Universitas Islam Negeri Sultan Syarif Kasim Riau, Pekanbaru \\ E-mail : suciayumawar@gmail.com¹, Zarnelly71@gmail.com², Arif.Marsal@uin-suska.ac.id ${ }^{3}$
}

\begin{abstract}
ABSTRAK
Salah satu organisasi kemasyarakatan yang berbasis kegiatan keagamaan di Indonesia adalah Majelis Dakwah Islamiyah (MDI) yang terletak di jakarta utara dan kota pekanbaru adalah lembaga dakwah yang mengemban amanat yang menjalankan dakwah Dinayah (agama), Insaniyah (kemanusiaan) dakwah Wathoniah (Patriotik). waktu yang dibutuhkan untuk membuat jadwal ceramah pada bulan ramadhan adalah lima bulan. Saat ini di MDI Pekanbaru terdapat 800 masjid/musalah dan 1088 mubaligh/mubalighah dan waktu yang dibutuhkan untuk membuat jadwal khutbah jum'at mubaligh adalah satu bulan untuk menyusun 4 bulan jadwal. Terdapat 407 masjid/musalah dan 499 mubaligh. serta harus memperhatikan empat buah kriteria, yaitu: (1) usia mubaligh; (2) kemampuan mubaligh; (3) alamat mubaligh, (4) tingkat kedisiplinan mubaligh. Penelitian ini membuat sistem informasi penjadwalan ceramah yang bisa menyusun jadwal secara otomatis menggunakan algoritma greedy untuk mengatasi permasalahan yang ada dan dapat membantu sekretaris dalam menyusun jadwal ceramah mubaligh, dengan waktu yang lebih cepat serta meminimalisir tingkat kesalahan dalam membuat jadwal (Jadwal Bentrok) antara tempat yang satu dengan tempat yang lain. Pendekatan analisis dan desain yang digunakan dalam penelitian ini adalah object oriented analysis and design (OOAD) dengan bantuan model unified modelling language (UML). Berdasarkan hasil pengujian blackbox, semua fitur-fitur di sistem ini berjalan 100\%. User acceptence test menunjukkan bahwa tingkat penerimaan pengguna terhadap sistem adalah $98 \%$.
\end{abstract}

Kata Kunci: Bulan Ramadhan, Greedy, Khutbah Jum'at, MDI Pekanbaru, Penjadwalan mubaligh.

yang dibutuhkan untuk membuat jadwal khutbah jum'at mubaligh adalah satu bulan untuk menyusun

\section{A. PENDAHULUAN}

Salah satu organisasi kemasyarakatan yang berbasis kegiatan keagamaan di Indonesia adalah Majelis Dakwah Islamiyah (MDI) yang terletak di jakarta utara dan kota pekanbaru adalah lembaga dakwah yang mengemban amanat yang menjalankan dakwah Dinayah (agama), Insaniyah (kemanusiaan) dakwah Wathoniah (Patriotik). Keberardaan organisasi ini dapat membimbing umat agar tidak tergelincir kepada perbuatan yang di murkai Allah SWT. Majelis Dakwah Islamiyah didirikan pada tanggal 17 Jumadil Awal $1398 \mathrm{H}$ bertepatan dengan 24 Mei 1978, dan beralamatkan di Jalan Arifin Ahmad Kelurahan Sidomulyo Timur Kecamatan Marpoyan Damai. MDI memiliki tugas membuat jadwal tempat ceramah mubaligh. Mubaligh akan diutus di 25 kecamatan yang terdapat di Kota Pekanbaru dan beberapa masjid yang terdapat di Kabupaten Kampar. Seperti Siak Hulu dan daerah Tambang.

Berdasarkan hasil wawancara ke wakil sekretaris MDI, waktu yang dibutuhkan untuk membuat jadwal ceramah pada bulan ramadhan adalah lima bulan. Saat ini di MDI Pekanbaru terdapat 800 masjid/musalah dan 1088 mubaligh/mubalighah sehingga dapat dihitung misal satu bulan Ramadhan terdapat 29 hari, maka terdapat 30.464 jadwal yang mungkin terjadi. Dan waktu
4 bulan jadwal. Terdapat 407 masjid/musalah dan 499 mubaligh. dan Selain itu lamanya penyusunan jadwal juga disebabkan dalam penyusunan jadwal harus memperhatikan empat buah kriteria, yaitu: (1) Usia Mubaligh, (2) Alamat Mubaligh. (3) Kemampuan Mubaligh), (4) Tingkat Kedisiplinan Mubaligh.

Masalah lain yang terjadi dalam sistem penjadwalan ceramah pada MDI kota Pekanbaru yaitu kesulitan dalam menyusun jadwal karena kriteria yang diikuti. Banyaknya jumlah mubaligh dan masjid/musalah sehingga sering terjadi jadwal bentrok.

Studi ini membangun sistem penjadwalan yang bisa menyusun jadwal tempat ceramah secara otomatis, sehingga sistem ini tidak menghasilkan jadwal yang bentrok (jadwal yang bersamaan) antara tempat yang satu dengan tempat yang lain, juga mempertimbangkan empat kriteria penyusunan jadwal yang telah dijelaskan sebelumnya. selain itu, mubaligh akan lebih mudah melihat jadwal dimana saja dan kapan saja. karena sistem yang dibangun berbasis web.

Penelitian ini menggunakan metode Algoritma Greedy. Metode ini dipilih karena telah berhasil menyelesaikan beberapa permasalahan penjadwalan, seperti: penjadwalan produksi 
singlestage pada mesin parallel [1], aplikasi penjualan komputer dengan metode crosseling dan upselling dilengkapi dengan algoritma greedy, penjadwalan pertandingan liga dengan algoritma greedy [2].

Berdasarkan penjelasan sebelumnya, maka studi ini membangun sistem informasi penjadwalan ceramah mubaligh berbasis web menggunakan algoritma greedy.

\section{B. LANDASAN TEORI B.1. \\ Penjadwalan}

Pengertian penjadwalan secara umum dapat diartikan seperti: "Scheduling is allocation of resources overtime to perform collection of risk", yang artinya penjadwalan adalah pengalokasi kan sumber daya yang terbatas untuk mengerjakan sejumlah pekerjaan (Nuraisyah, 2017) [3]. Penjadwalah adalah proses pengorganisasian, pemilihan, dan pemberian waktu dalam penggunaan sumber daya untuk melaksanakan aktivitas yang diperlukan dalam menghasilkan output yang diinginkan, dengan memenuhi waktu yang ditetapkan dan kendala-kendala hubungan antara waktu dan aktivitas (Morton dan Pentico, 1993 dikutip oleh Hodianto, 2011)

\section{B.2. Algoritma Greedy}

Algoritma greedy secara umum mengidentifikasikan bahwa implementasi akan menggunakan sederetan pilihan sementara yang terbaik, yang akan memicu pilihan terbaik yang bersifat final. Jika memang demikian keadaannya, algoritma akan menghasilkan solusi yang optimal (bukan yang terbaik); jika tidak, solusi suboptimal akan ditemukan. Meski demikian, untuk banyak permasalahan, tidak selalu kita menemukan solusi terbaik, sehingga kasus seperti ini algoritma greedy bekerja dengan hasil yang cukup baik.

(Nugroho, 2009) [4].

\section{B.3. Website}

Website adalah suatu ruang informasi dimana sumbe rsumber daya yang berguna diidentifikasikan pengenalan global yang

\section{METODOLOGI PENELITIAN}

disebut Uniform Resource Locator (URL)“. Secara termologi, pengertian website adalah kumpulan dari halaman-halaman situs atau link yang biasanya terangkum dalam sebuah domain atau subdomain yang tepatnya berada didalam World Wide Web (WWW) di Internet. Sebuah halaman web adalah dokumen yang ditulis dalam format HTML (Hyfer Text Markup Langguage), yang hampir selalu bisa di akses melalui HTTP, yaitu protokol yang menyampaikan informasi dari server website untuk ditampilkan kepada para pemakai melalui web browser. Halamanhalaman dari sebuah website yang diidentifikasikan oleh URL (Uniform Resource Locator) biasa Disebut homepage atau domain name. (Rahdian, 2018 dikutip oleh Artika, 2014) [5].

\section{B.4. Blackbox Testing}

Pengujian fungsional atau blackbox testing merupakan pendekatan pengujian yang ujinya diturunkan dari spesifikasi program atau komponen. Sistem merupakan kotak hitam yang perilakunya hanya dapat ditentukan dengan mempelajari input dan output yang berkaitan. Nama lain untuk cara ini adalah pengujian fungsional karena pengujian hanya berkepentingan dengan fungsionalitas dan berfokus pada impelemtasi perangkat lunak. Pendekatan ini dapat diterapkan pula pada sistem yang disusun sebagai fungsi atau sebagai objek. Pengujian memberikan input kepada komponen atau sistem dan meliputi output yang dihasilkan. Jika output bukan merupakan yang diramalkan, berarti uji telah dengan hasil mendeteksi masalah dengan perangkat lunak tersebut.

B.5. User Acceptance Test (UAT) merupakan sebuah pengujian sistem yang ditunjukan kepada pengguna sistem tersebut, dengan menggunakan beberapa scenario pengujian setelah aplikasi selesai dibuat. UAT umumnya dilakukan oleh klien atau pengguna akhir, biasanya tidak fokus pada identifikasi masalah sederhana seperti kesalahan ejaan, maupun di cacat showstopper, seperti crash perangkat lunak [6].

Metodologi yang diterapkan dalam penelitian ini mengadopsi metode waterfall yang dapat dilihat pada Gambar 1. Metodologi Penelitian 


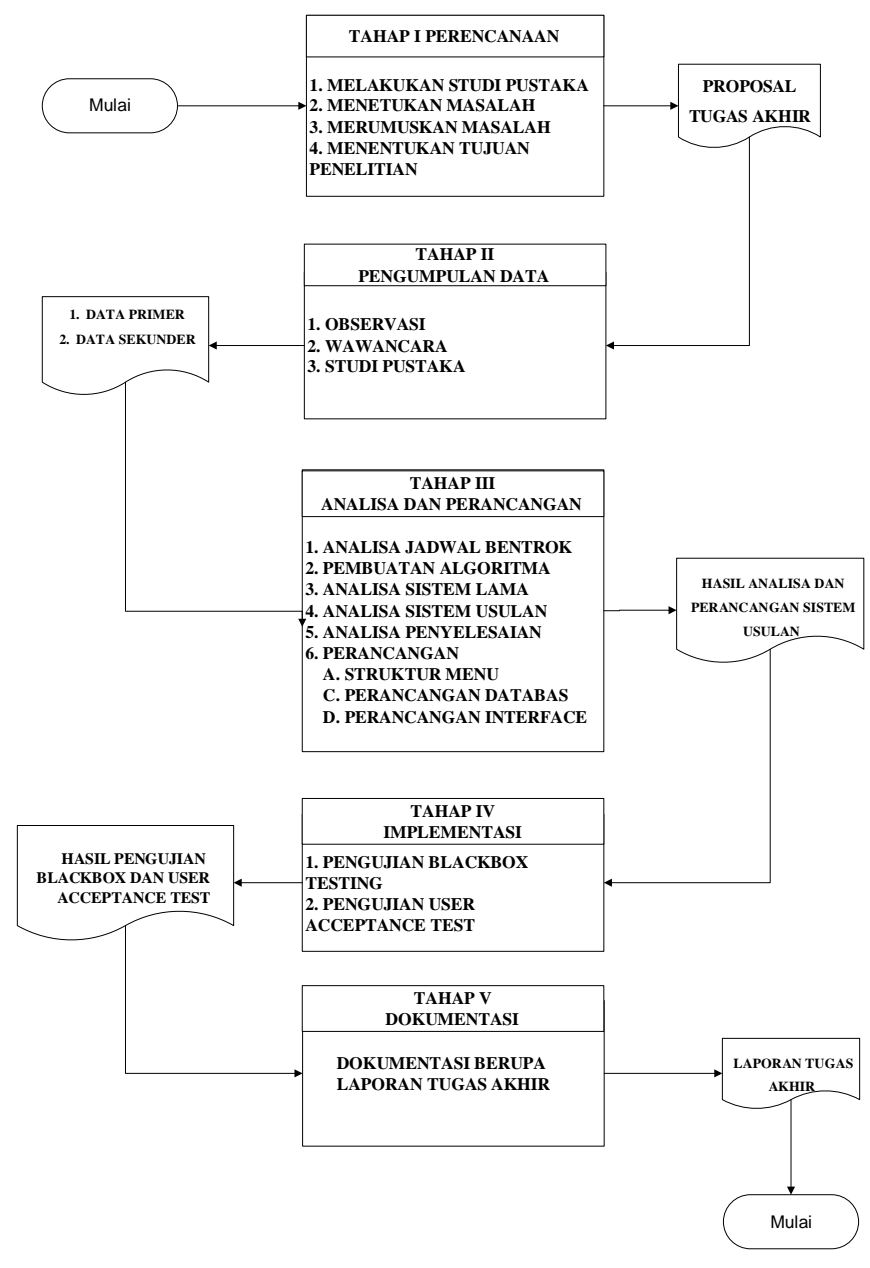

\section{C.1. Tahap Perencanaan}

Tahap perencanaan adalah tahapan yang harus direncanakan saat akan melakukan penelitian, data yang direncanakan adalah:

a. Melakukan Studi Pustaka

Membaca literature sebagai bahan persiapan menentukan masalah.

b. Menentukan Masalah Menentukan masalah yang akan diangkat sebagai topik utama penelitian.

c. Merumuskan Masalah Merumuskan masalah apa yang dikaji dalam Tugas Akhir ini beserta ruang lingkup atau batasan masalah pada Tugas Akhir ini, yaitu merumuskan masalah yang akan diteliti, Menentukan permasalahan apa saja yang akan dibahas dengan cara mengamati kegiatan yang ada pada MDI Kota Pekanbaru. Hasil yang diperoleh dari tahap ini adalah berupa rumusan masalah dari Tugas Akhir.

d. Menentukan Tujuan Penelitian

Penentuan tujuan berfungsi untuk memperjelas tentang apa saja yang menjadi sasaran dari penelitian ini, sehingga apa yang dikerjakan dalam penelitian berdasar dari tujuan. Tujuan penelitian ini adalah membangun sistem pengolahan data nilai menggunakan metode waterfall.

\section{C.2. Tahap Pengumpulan Data}

Tahap ini merupakan tahap dimana penulis akan mengumpulkan data-data yang terkait dari pihak yang bersangkutan untuk kemudian diolah sebagai bahan penelitian. Adapun metode pengambilan data yang dilakukan penulis adalah:

a. Observasi 
Observasi dilakukan di MDI

Kota Pekanbaru yang beralamatkan di Jl.Rambutan, dalam observasi ini yang didapat berupa data jadwal yang sudah dicetak, data mubaligh dan data mesjid.

b. Wawancara

Peneliti bertatap muka langsung dengan sumber informasi untuk mengajukan pertanyaan-pertanyaan secara langsung. Wawancara dilakukan di MDI Kota Pekanbaru dengan narasumber H. Asrori, MA selaku sekretaris, dengan memberikan beberapa pertanyaan mengenai hal-hal yang berhubungan dengan penelitian ini.

c. Studi Pustaka

Tahap ini dilakukan dengan cara membaca buku, jurnal serta penelitian- penelitian terdahulu sebagai referensi.

\section{C.3. Tahap Analisa dan Perancangan}

Berikut adalah tahapan dari analisa dan perancangan:

a. Analisa Jadwal Bentrok Pada analisa jadwal bentrok ini, penulis melakukan analisa terhadap dokumen jadwal yang pernah dibuat oleh wakil sekretaris yang terdapat jadwal bentroknya.

b. Pembuatan Algoritma Pembuatan algoritma Greedy ini disusun berdasarkan empat kriteria pembatan jadwal yang telah ditentukan

c. Analisa Sistem Lama. Analisa sistem lama dibuat dengan wawancara kepada wakil sekretaris. Selain itu juga dilakukan observasi proses pembuatan jadwal yang dilakukan oleh wakil sekretaris. Lalu hasil analisa dimodelkan dalam bentuk flowchart dengan bantuan tools Microsoft Visio 2010. d. Analisa Sistem Usulan. Gambaran rancangan sistem yang akan dibangun nantinya dengan berbasis web. Analiswa sistem usulan ini, digunakan untuk mengetahui alur sistem serta fungsifungsi menu yang akan dibuat. Model yang digunakan adalah use case diagram, class diagram, activity diagram, squence diagram. Tools yang digunakan adalah Microsoft Office Visio.

e. Analisa Penyelesaian Pada tahapan ini dilakukan analisa penyelesaian terhadap kasus permasalahan, dalam hal ini menggunakan algoritma greedy

f. Perancangan Sistem

\section{C.4. Tahap Implementasi}

berikut ini adalah tahap dari implementasi yaitu:

a. Tahap Pengujian Sistem Tahap ini dilakukan dengan menguji sistem apakah masih terdapat bug atau kesalahan yang dapat mengganggu kinerja sistem yang dibuat.

\section{C.5. Tahap Dokumentasi}

Pada tahap ini dilakukan penulisan laporan Tugas Akhir dimulai dari Bab I sampai dengan selesai.

\section{ANALISA DAN PERANCANGAN}

\section{D.1. Analisa Sistem Lama}

Analisa sistem lama merupakan langkah utama yang harus dilaksanakan sebelum memberikan bentuk sistem yang diusulkan. Karena pada dasarnya harus ada landasan untuk membangun sebuah sistem, bisa berupa permasalahan yang terjadi dan harus segera diselesaikan agar tidak

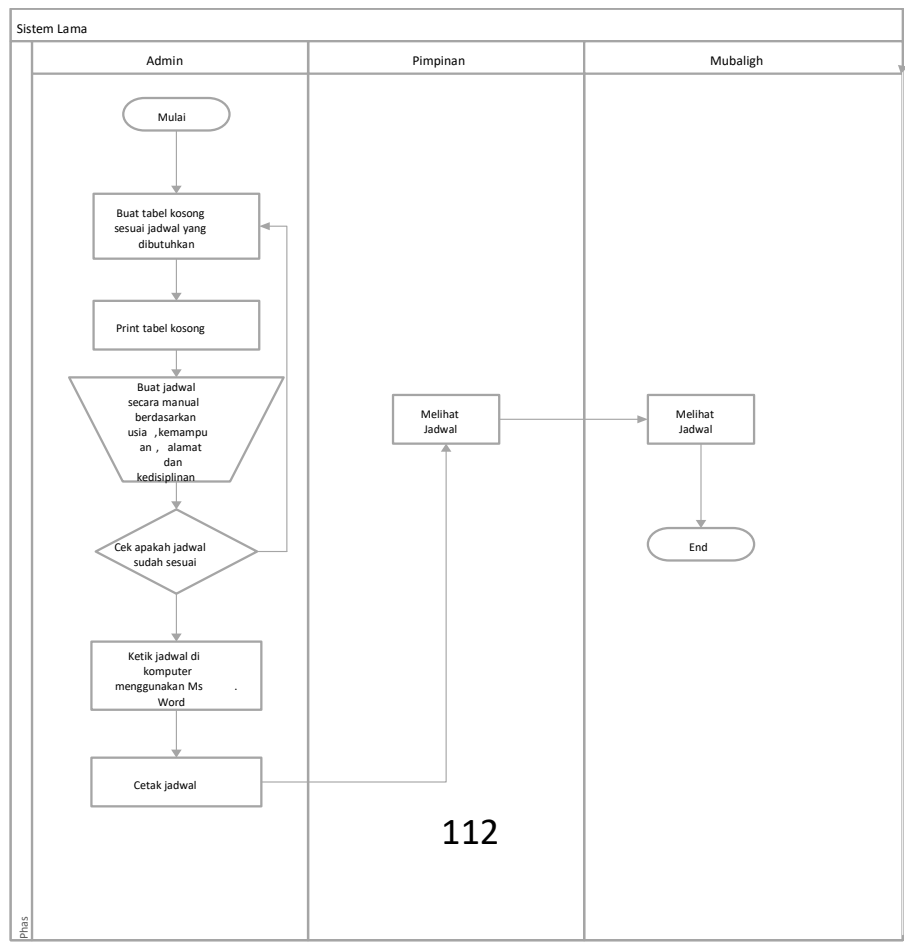


menggangu proses bisnis. Proses yang sedang berjalan dapat dilihat pada Gambar 4.1.

Pada Gambar 4.1. MDI Pekanbaru terdapat beberapa tahapan dalam pembuatan jadwal Ceramah. Langkah pertama sekretaris membuat tabel kosong menggunakan Microsoft Word berdasarkan sejumlah jadwal yang dibutuhkan. lalu sekretaris MDI membuat jadwal berdasarkan dengan 4 pertimbangan yaitu kemampuan, usia, alamat, dan kedisiplinan. Setelah jadwal selesai sekretaris MDI mengecek apakah jadwal sudah sesuai dengan 4 pertimbangan yang telah disebutkan dan tidak adanya jadwal bentrok. setelah itu sekretaris mencetaknya untuk dibagikan ke pimpinan dan ke setiap mubaligh. Berdasarkan analisa terhadap sistem yang sedang berjalan pada kantor MDI kota Pekanbaru diketahui beberapa permasalahan, yaitu:

1) Sering terjadi kesalahan dalam pembuatan jadwal sehingga terjadinya jadwal bentrok.

2) Jadwal yang disusun terkadang tidak sesuai dengan empat kriteria yang dipertimbangkan dalam penyusunan jadwal Ceramah.

3) Kesulitan dalam hal pencarian penjadwalan yang lalu.

4) Lamanya waktu yang dibutuhkan dalam penyusunan jadwal Ceramah mubaligh.

\section{D.2. Analisa Sistem Baru}

Perancangan sistem usulan akan memberikan penjelasan dan gambaran secara utuh mengenai bentuk dan rancangan kerja dari sistem tersebut. Sistem usulan mempermudah pembuatan jadwal cermah tanpa terjadinya jadwal bentrok. Untuk mempersingkat waktu penyusunan jadwal pada sistem yang sedang berjalan. Sistem usulan juga akan membuat jadwal secara otomatis berdasarkan data mubaligh, data masjid dan data lokasi yang telah dimasukan sebelumnya. Hasil penyusunan jadwal yang dilakukan oleh sistem juga mempertimbangkan empat kriteria penyusunan jadwal yang telah dijelaskan sebelumnya. Setelah jadwal dibuat oleh sistem, jadwal bisa langsung dilihat oleh pimpinan dan mubaligh.

\section{D.3. Sistem Usulan Menggunakan Algoritma Greedy \\ Untuk memperjelas akan skema pada} subbab sebelumnya, metode akan dipakai untuk menyelesaikan masalah berikut. Ada 4 kriteria dalam pembuatan sistem penjadwalan. kriteria tersebut diberi simbol A: Usia, B:Kemampuan, C:Alamat, D:Disiplin. dan Masjid di beri simbol $1,2,3,4$. setiap mubaligh harus mengikuti empat kriteria yang telah di tentukan. Sekarang kita akan memakai metode algoritma greedy pada subbab sebelumnya untuk menyelesaikan masalah ini.

Inisialisasi himpunan $\mathrm{S}$, = Himpunan Mubaligh yang belum berdasarkan kriteria $\{\mathrm{A}, \mathrm{B}, \mathrm{C}, \mathrm{D}\}$.

Inisialisasi himpunan $\mathrm{C},=$ Mubaligh sesuai kriteria.

Berdasarkan Usia, dekat dengan tempat tinggal: $\mathrm{S}:=\mathrm{A}, \mathrm{B}, \mathrm{C}, \mathrm{D}, \mathrm{E}, \mathrm{F}$,

Masjid $=1,2,3,4,5,6, \mathrm{C}=$

$\mathrm{A} 1, \mathrm{~B} 2, \mathrm{C} 3, \mathrm{D}, 4$.

Untuk mubaligh tua yang tidak mendapatkan masjid dekat dengan tempat tinggal di letakkan secara acak.

Mubaligh berkemampuan senior.

$\mathrm{S}:=\mathrm{A}, \mathrm{B}, \mathrm{C}, \mathrm{D}, \mathrm{E}, \mathrm{F}$,

Masjid Besar $=1,2,3,4,5,6, \mathrm{C}=$ A1, B2, C3, D, 4 .

Untuk mubaligh berkemampuan yang tidak mendapatkan masjid besar di letakkan secara acak.

Mubaligh yang ceramah dekat dengan tempat tinggalnya atau satu kecamatan. S:= A, B, C, D, E, $\mathrm{F}$,

Masjid satu kecamatan $=1,2,3,4,5,6, \mathrm{C}=$ A1, B2, C3, D,4. E,5.

Susun Jadwal mubaligh secara random.

\section{D.4. Diagram Use Case}

Berikut merupakan penggambaran sistem usulan dalam bentuk usecase yang dapat dilihat pada Gambar 3. Diagram use case sistem usulan. 


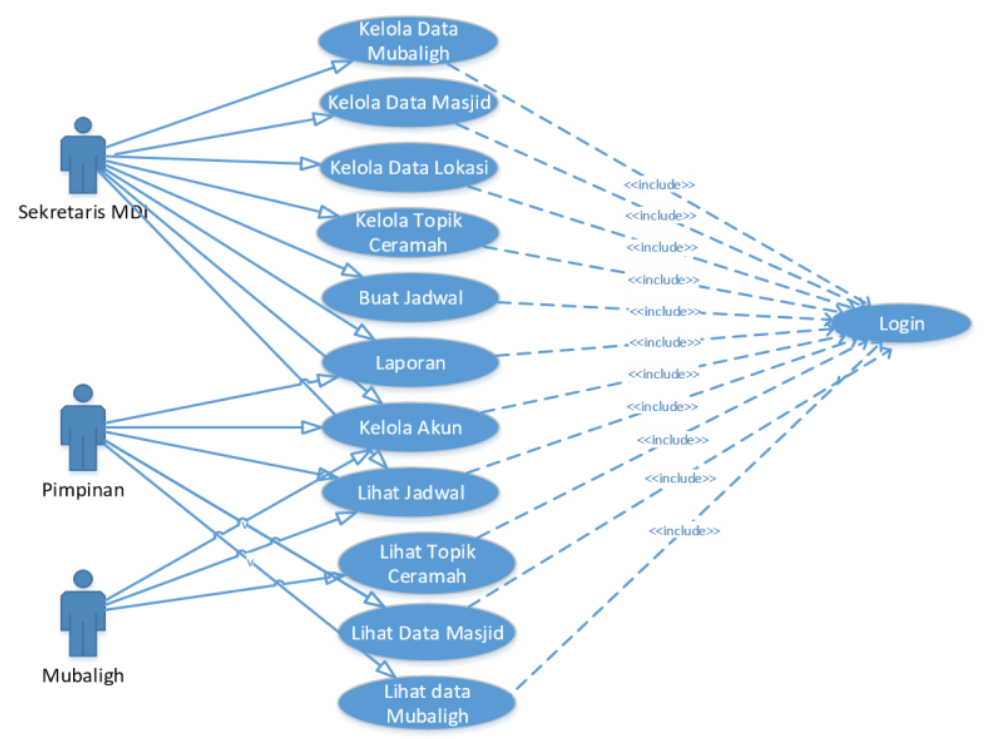

Gambar 3. Use case Diagram

\section{Karakteristik Pengguna}

Aktor yang terlibat dalam sistem informasi penjadwalan dapat di lihat pada tabel 1 . Tabel

1. Daftar Aktor

\begin{tabular}{|c|c|l|}
\hline No. & Aktor & \multicolumn{1}{|c|}{ Deskripsi } \\
\hline 1. & $\begin{array}{c}\text { Sekretaris MDI } \\
\text { (Admin) }\end{array}$ & $\begin{array}{l}\text { Sekretaris bertugas memberikan hak akses kepada } \\
\text { pengguna sistem, serta menginputkan data para } \\
\text { mubaligh, masjid dan lokasi, dan menyusun penjadwalan } \\
\text { ceramah. }\end{array}$ \\
\hline 2. & Pimpinan & $\begin{array}{l}\text { Pimpinan pengecekan, pengambilan keputusan, melihat } \\
\text { jadwal dan monitoring laporan data mubaligh }\end{array}$ \\
\hline 3. & Mubaligh & $\begin{array}{l}\text { Bagian ini dapat melihat informasi mengenai jadwal } \\
\text { ceramah. }\end{array}$ \\
\hline
\end{tabular}

Tabel 1. diatas adalah tabel daftar aktoraktor yang terlibat di dalam sistem penjadwalan ceramah. Aktor-aktor yang terlibat antara lain admin, pimpinan, mubaligh.

\section{D.5. Diagram Activity}

Diagram Activity menggambarkan aliran kerja atau aktivitas dari sebuah sistem atau proses bisnis.

1. Diagram Activity kelola jadwal

Berikut adalah Diagram kelola jadwal dan yang dapat dilihat pada Gambar 4. di bawah ini.

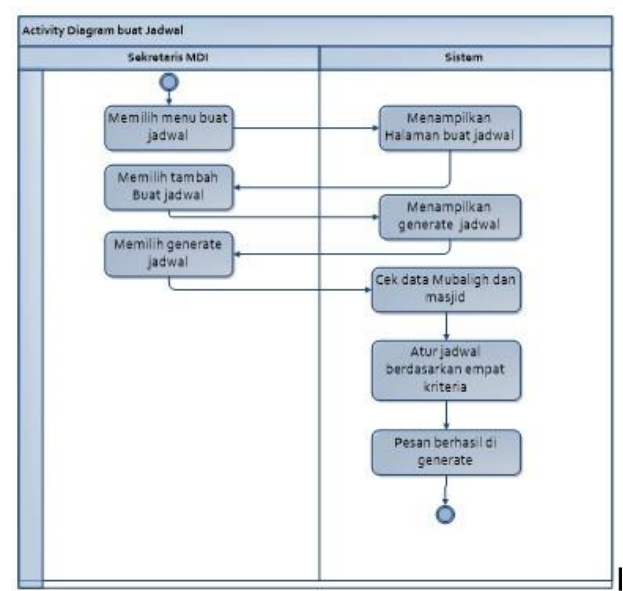

Gambar 4. Diagram Activity Kelola Jadwal 
Pada Gambar 4. merupakan diagram kelola jadwal pada sistem admin. Admin dapat membut dan mengelola jadwal.

2. Berikut adalah Diagram Activity data mubaligh yang dapat dilihat pada Gambar 5. di bawah ini.

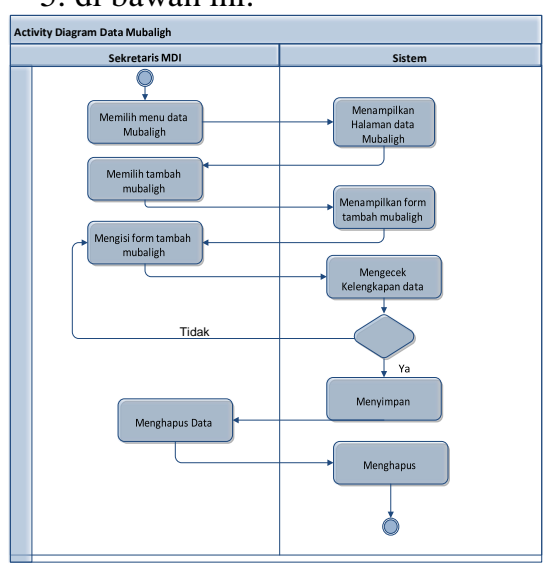

Gambar 5. Diagram Activity Data Mubaligh

Pada Gambar 5. merupakan diagram activity Data Mubaligh. Admin dapat melakukan tambah, edit dan hapus data mubaligh.

\section{E. IMPLEMENTASI SISTEM E.1. Hasil Implementasi Sistem}

Hasil implementasi sistem halaman sekretaris dilakukan setalah sekretaris masuk kedalam sistem. Sekretaris merupakan hak akses yang dapat berfungsi mengontrol seluruh aktifitas pada sistem, seperti; (1) halaman login; (2) halaman utama sistem; (3) halaman Kelola Data Masjid; (4) halaman Kelola Data Mubaligh; (5) halaman Kelola Data Lokasi; (6) halaman topik ceramah (7) halaman sekretaris MDI; (8) halaman pimpinan; (9) halaman jadwal khutbah; (10) halaman jadwal ramadhan; (11) halaman laporan; (12) halaman ubah password;

\section{D.6. Diagram Class}

Diagram Class adalah diagram yang menunjukan kelas-kelas yang ada di sistem informasi pengolahan nilai dan hubungannya secara logika. Diagram class ini menggambarkan struktur statis dari sistem. Diagram class yang dibuat pada tahap desain merupakan deskripsi lengkap dari kelas-kelas yang ditangani oleh sistem, dimana masing-masing kelas telah dilengkapi dengan atribut dan operasi yang diperlukan. Diagram class sistem informasi pengolahan nilai berbasis web akan dijelaskan pada Gambar 6. di bawah ini.

Hasil implementasi dapat dilihat pada Gambar 7 sampai Gambar 9 di bawah ini.

Gambar 7 merupakan halaman data mubaligh, pada halaman ini sekretaris bisa mengubah data mubaligh. Halaman ini terdapat tombol berlabel "Tambah Data Mubaligh" yang berfungsi untuk membuka halaman tambah data mubaligh. Di samping kanan atas tabel data kategori terdapat pencarian data mubaligh. Pencarian data bisa dilakukan berdasarkan nama mubaligh. Sedangkan Di sebelah kiri atas textbox pencarian terdapat tombol untuk menentukan jumlah data per halaman pada tabel.

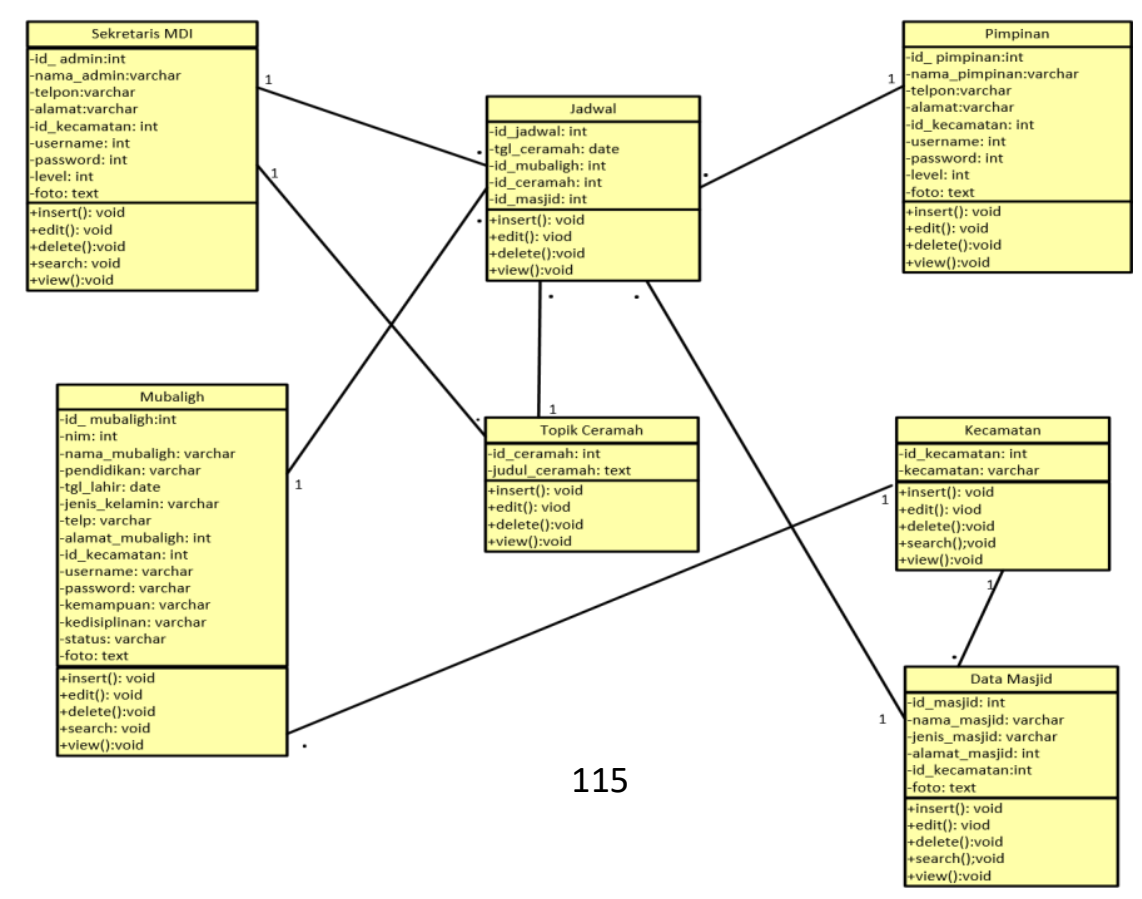


Pada tabel data mubaligh terdapat delapan buah kolom, yaitu: (1) kolom nomor; (2) kolom nim; (3) kolom nama mubaligh; (4) kolom kecamatan; (5) kolom usia; (6) kolom kemampuan; (7) kolom kedisiplinan; (8) kolom aksi. Pada kolom delapan terdapat tiga buah tombol aksi, yaitu: (1) tombol untuk lihat data mubaligh keseluruhan; (2) tombol ubah ubah untuk mengubah data nubaligh; dan (3) tombol hapus untuk menghapus data mubaligh.

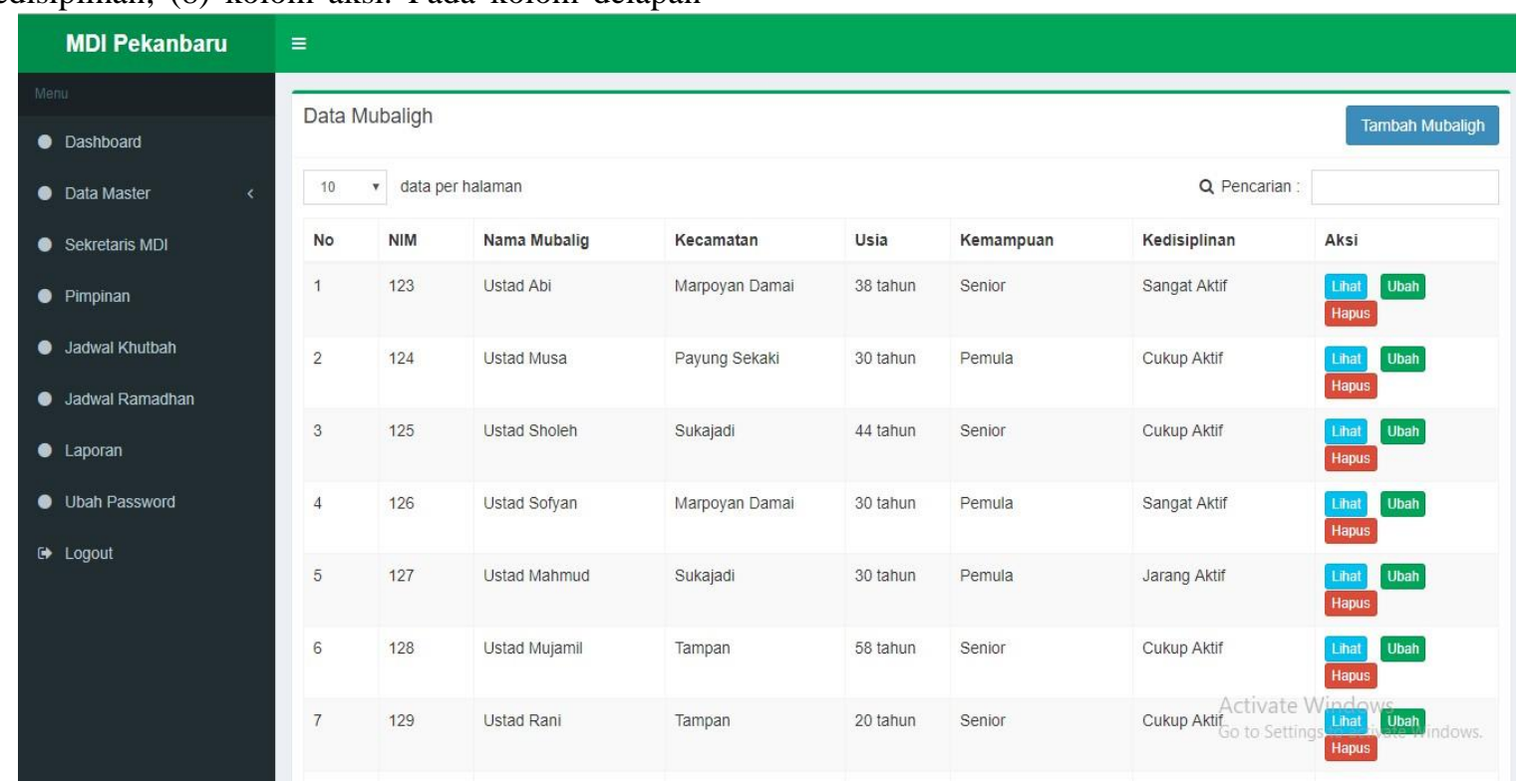

Gambar 7. Halaman Menu Data Mubaligh

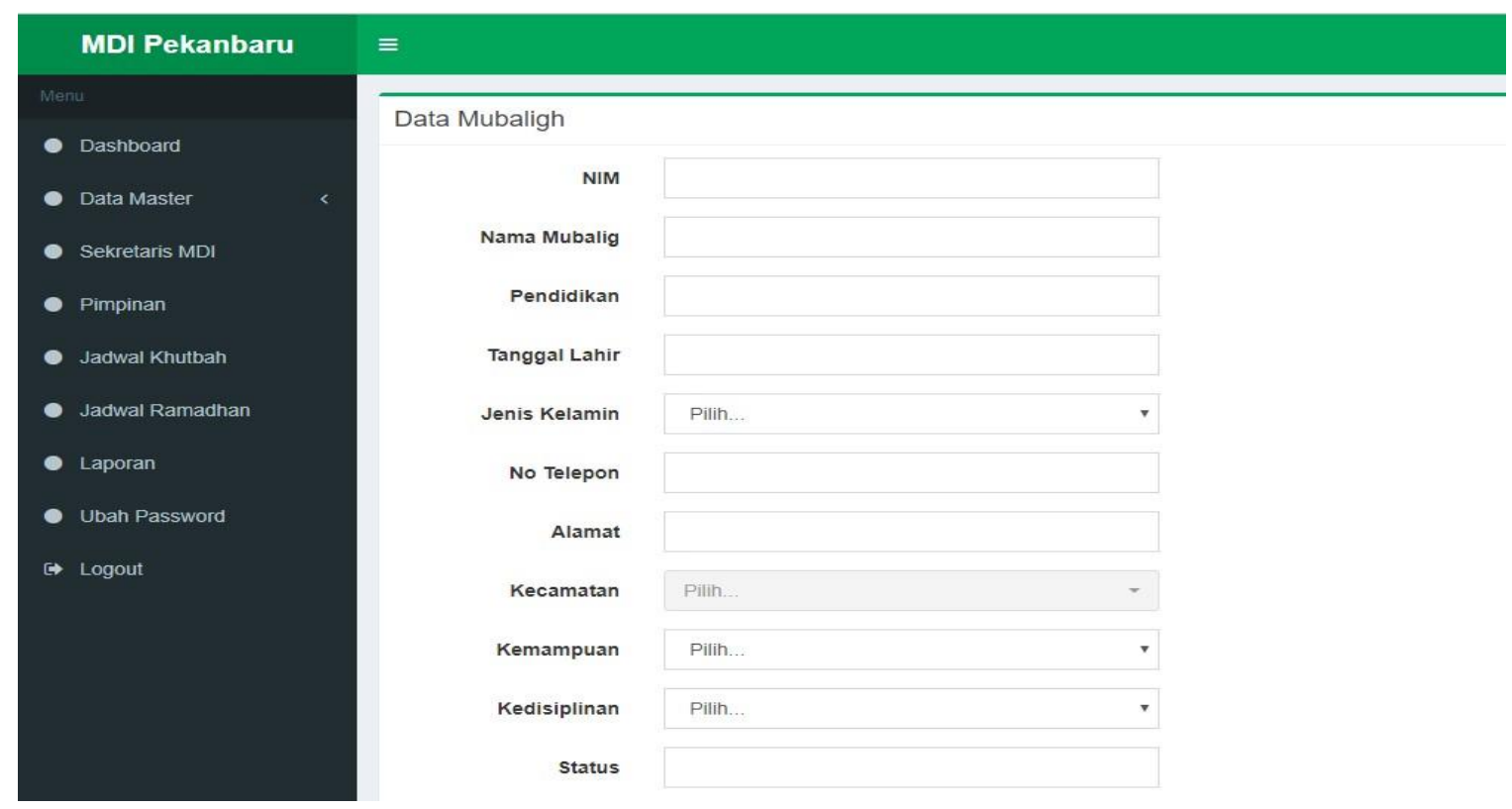

Gambar 8. Halaman Tambah Data mubaligh 


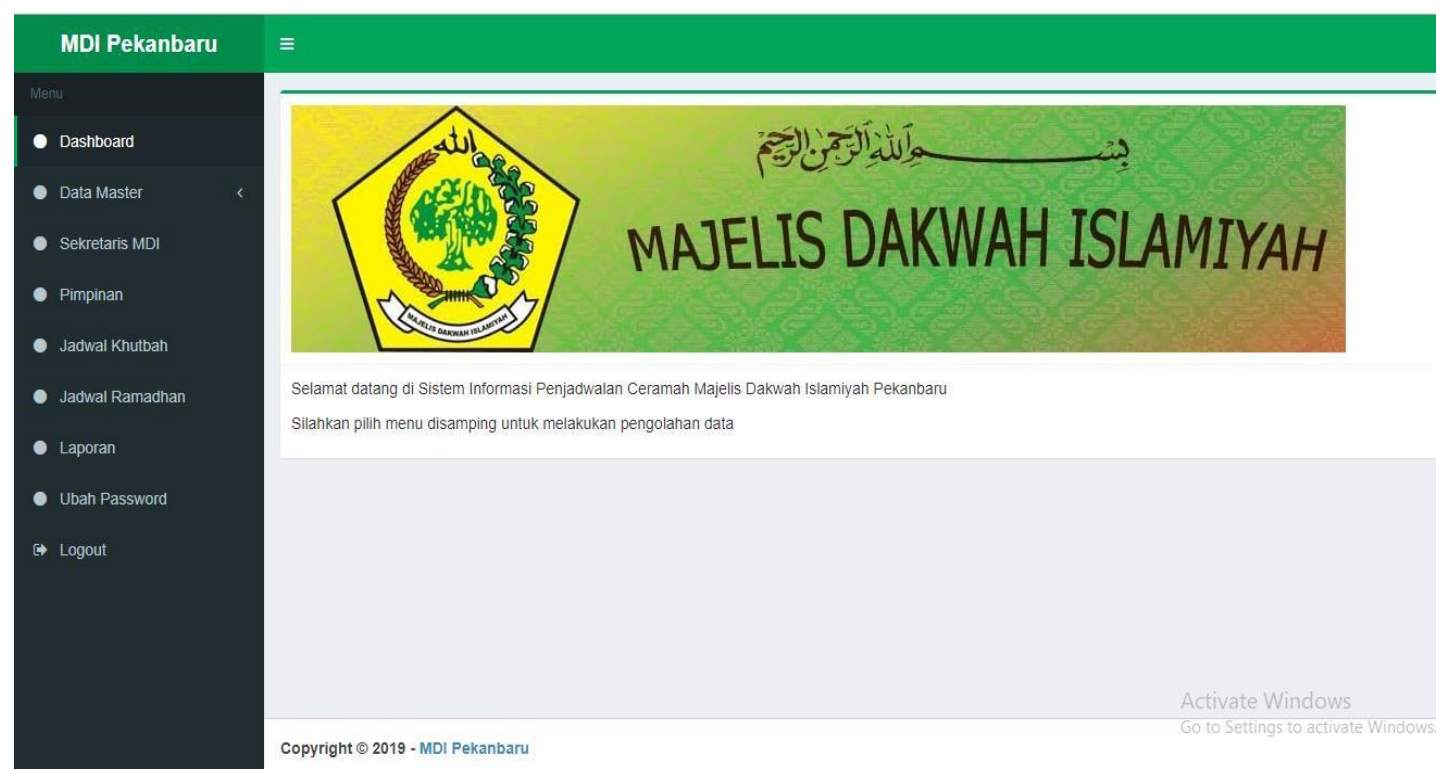

\section{E.2. Pengujian Sistem}

Pengujian sistem yang digunakan adalah jenis pengujian black box dan UAT. Jenis pengujian blackbox adalah dimana proses uji ditampilkan dalam bentuk tabel yang didalamnya menjelaskan tentang deskripsi pengujian, prekondisi awal, prosedur pengujian, data masukkan yang digunakan, keluaran yang diharapkan, kriteria evaluasi hasil, hasil yang didapat dari pengujian dan terakhir kesimpulan pengujian. Teknik yang digunakan untuk melakukan test cases pada sistem yang dibangun ini disebut Functional Analysist.

Pada pengujian blackbox yang di lakukan tidak ditemukan adanya kegagalan dalam setiap menu pada sistem pengolahan nilai. Berdasarkan hasil pengujian dengan sample uji yang telah dilakukan memberikan kesimpulan bahwa sistem ini dapat digunakan dengan baik, namun pengujian tersebut dapat dikatakan belum sempurna, karena hanya dilakukan pada satu sisi pengujian. Dari semua yang telah dilakukan dalam pengujian ini diharapkan dapat mewakili pengujian fungsi yang lain.

\section{F. PENUTUP F.1. Kesimpulan}

Berdasarkan hasil penelitian yang telah dilakukan pada Majelis Dakwah Islamiyah Kota Pekanbaru, maka dapat ditarik kesimpulan yaitu:

a. Dengan adanya sistem informasi penjadwalan ini, dapat membantu sekretaris dalam menyusun jadwal ceramah mubaligh, dengan waktu yang lebih cepat.

b. Dengan adanya sistem informasi penjadwalan ini, dapat mempercepat dan meminimalisir tingkat kesalahan dalam membuat jadwal (Jadwal Bentrok).

c. Berdasarkan hasil pengujian yang dilakukan oleh sekeretaris, pimpinan dan 3 mubaligh dengan menggunakan black box ,menu-menu yang ada pada sistem berjalan $100 \%$.

d. Berdasarkan hasil pengujian menggunakan metode user accepten test, pengujian berhasil $98,18 \%$

\section{F.2. Saran}

a. Berdasarkan hasil user acceptence test yang dilakukan oleh lima orang pengguna (sekretaris, pimpinan dan 3 mubaligh) bentuk desain dari sistem informasi penjadwalan ini perlu lebih disempurnakan lagi.

b. Dalam penyusunan jadwal masih ada beberapa tempat ceramah mubaligh yang berada diluar kecamatan tempat tinggalnya, maka dari itu diperlukan pembuatan jadwal mubaligh dengan menggunakan algoritma yang berbeda.

\section{DAFTAR PUSTAKA}

[1] Ahmad, Juniar "Penerapan Algoritma Greedy pada Penjadwalan Produksi Single-Stage dengan Parallel Machine di Industri Konveksi". Jurnal JSM STMIK Mikroskil, Vol. 16, No. 2, 1412-0100, 2015.

[2] William. Penjadwalan Pertandingan Liga Dengan Algoritma Greedy. Institut Teknologi Bandung. 2008.

[3] Nuraisyah, Permana I, Salisah FN. Sistem Penjadwalan Otomatis Tempat Khutbah Jum'at Mubaligh. Jurnal Ilmiah Rekayasa dan 
Jurnal Ilmiah Rekayasa dan Manajemen Sistem Informasi, Vol. 5, No. 1, Februari 2019, Hal. 109-118 e-ISSN 2502-8995 p-ISSN 2460-8181

Manajemen Sistem Informasi. Vol. 3, No. 1, 2502-899, 2017.

[4] Nugroho, Adi, “Algoritma Struktur Data Dengan C\#” Andi, Yogyakarta. 2009.

[5] Artika, Gugi. "Sistem Informasi Penjualan Gadget Berbasis Web Pada Toko Mitra Abadi”. Jurnal Paradigma, Vol. XVI, no. 2014.

[6] Zarnelly,dan Adelia, Della. "Rancang Bangun Media Pelayanan Umum Desk Info di Pengadilan Tinggi Agama Pekanbaru". Jurnal Informatika, Vol.14,No.1 Juni 2014. 